\title{
Assessing Observation Methods for Landscape Planning Practice in Rural Villages
}

\author{
Barbora Lipovská ${ }^{1}$, Roberta Štěpánková ${ }^{2}$ \\ ${ }^{1}$ Horticulture and Landscape Engineering Faculty, Slovak University of Agriculture, Nitra, Slovakia \\ ${ }^{2}$ Department of Garden and Land Architecture, Horticulture and Landscape Engineering Faculty, \\ Slovak University of Agriculture, Nitra, Slovakia \\ Email: barbora.lipovska@uniag.sk
}

Received July 23 ${ }^{\text {rd }}, 2013$; revised August $25^{\text {th }}, 2013$; accepted September $2^{\text {nd }}, 2013$

\begin{abstract}
Copyright (C) 2013 Barbora Lipovská, Roberta Štěpánková. This is an open access article distributed under the Creative Commons Attribution License, which permits unrestricted use, distribution, and reproduction in any medium, provided the original work is properly cited.
\end{abstract}

\begin{abstract}
In recent years, people's behaviour has become attractive not only for psychologists and sociologists but also for urban planners, architects, landscape architects and all those involved in designing people's environment. Community has its own interest in the site that we should consider. This paper identifies peoplespace relations and reflects on the implications from theory and practice in landscape architecture, in relation to the use and potential physical change to public open space in rural settlements. As far as is known, there are no specific methodologies for assessing the use of rural public areas-public spaces in villages. This paper presents observation methodology providing information of the form of public spaces, their users and how public spaces are used. These surveys are important for landscape architects who design public spaces not just with vegetation but with hard landscape features (such as outdoor furniture, paths, and playgrounds).
\end{abstract}

Keywords: Observation Methods; Rural Public Spaces; Community; Design; Quality; Landscape Planning

\section{Introduction}

In the past decade, social goals have become secondary to economic motivation (Carr, 1992). The empirical basis for much design decision-making is lacking (Forsyth, 2007; Frick, 2007 ) and new techniques that offer more reliable ways of predicting and understanding use can be valuable tools (e.g. Thwaites et al., 2005; Porta et al., 2008, 2009). The research described here is an attempt to design the observation methodology for designing public spaces in landscape planning praxis. This paper explores the effectiveness of direct observation methods and described the obtained information and their value for assessing public spaces and argues for more comprehensive ways of looking at the usage-design relationship.

\section{Social Understanding of Public Spaces}

The public space is a social space such as town square that is generally open and accessible (Štěpánková et al., 2012). Public space is space we share with strangers, people outside our immediate communities of relatives, friends, or work associates. It is space for politics, religion, commerce, sport; space for peaceful coexistence and impersonal encounter. The character of public space expresses our public life, civic culture, and everyday discourse (Madanipour, 1996). For Carmona (2003) is public space a discretionary environment: people have to use these spaces, but conceivably could choose which public spaces to use. If they are to become peopled and animated, these spaces must offer what people want, in an attractive and safe environment (Lynch, 1960, 1984).
Public space design has a special responsibility to understand and serve the public good, which is only partly a matter of aesthetics (Carr, 1992). When designs are not grounded in social understanding, they may fall back on the relative certainties of geometry, in preference to the apparent vagaries of use and meaning (Carmona, 2003).

The fact that society and space are clearly related was the main point of the planner Patrick Geddes. He taught that before attempting to change a place, one must seek out its essential character on foot in order to understand its patterns of movements, its social dynamics, history and traditions, its environmental possibilities (Hough, 1990). In Germany before the Second World War, Martha Muchow (1966) started to apply observation methodologies. Her approach was based on studies of living space for urban children in Hamburg. "The area has been observed in a limited (specified) time and the behaviour of all children had been caught almost as illuminated by a flashbulb. By this flashbulb method, we can create a momentary image that shows who is using a public space, and in which part of the space the activity is located. The order of snapshots gives us a representation of how, where and by whom is public space used (Koll, 2009).

\section{Behaviour Research}

Environment-behaviour research that uses behaviour mapping as a way of understanding the interaction between people and place has been undertaken for several decades (Ittelsson, 1970). Beginning in the 1960s researches such as Jane Jacobs (1962), Kevin Lynch (1960, 1984), William H. Whyte (1980), 
Clare Cooper Marcus and Francis (1998) and the Danish designer Jan Gehl $(2000,1996)$ emphasized the need to base urban design on study of how people actually experience and use urban environments. Observation was seen as a method "with a very limited investment of time the investigators can achieve considerable insight into the actual use of designed places" (Cooper Marcus \& Francis, 1998: 346). A new discipline of environmental design emerged; devoted to researching how built environments work for people (Wheeler, 2004) and to demonstrate their association with particular sites (Bechtel et al., 1987).

An American urbanist, organizational analyst, journalist and people-watcher, William H. Whyte (1980), studied human behaviour in urban settings. He observed and film analysed plazas, urban streets, parks and other open spaces in New York City. Whyte walked the city streets for more than 16 years. As unobtrusively as possible, he watched people and used time-lapse photography to chart the meanderings of pedestrians. What emerged through his intuitive analysis is an extremely human, often amusing view of what is staggeringly obvious about people's behaviour in public spaces, but seemingly invisible to the unobservant (PPS, 2001).

In 1984 Francis (1984) presented a method of downtown and neighbourhood planning which considered the importance of traffic mapping, parking problems and pedestrian flow mapping. activity mapping as useful information for planning process was proved in Davis, California (USA) as a new design solution based on the activity analyses.

Another urban pioneer observing public spaces and people's behaviour is the Danish architect and city planner Jan Gehl. In his pioneering book Life between Buildings: Using Public Space Gehl (2000) took a remarkably perceptive look at different types of outdoor spaces and their social uses. What is most needed, he argued, is an increase in optional activities taking place in the public realm. The number and variety of human interactions, especially chance meetings in public space, was in his view the way to a healthier urban community. Analyzing public spaces within Copenhagen, he found places such as the Stroget (one of Europe's pioneering pedestrian streets) and the Tivoli Gardens particularly conductive to social life (Gehl \& Gemzoe, 1996). Although many of Gehl's observations may seem common sense today, they then represented a major departure from modernist urban design practices in which abstract architectural principles, rather than careful observation of how people actually use places, often dictated urban form. Behaviour observation is also described by Wheeler (2004), as the one of the methods to provide factual information for improved urban design. According to Whyte (1980) by observing what people do, rather than just listening to what they say, is designer able to put an end to some of the deep-seated and destructive myths about what people want from their cities and public spaces. As the Project for Public Spaces (2001) advises, when you observe a space you learn about how it is actually used, rather than how you think it is used. Šilhánková et al. (2006) argues that through the analysis of behaviour mapping it is possible to determine human activities performed in public space and what kind of conditions are necessary to prevent and develop these activities. Based on the results of this analysis it is possible to design the outdoor furniture such as benches, trash cans, clocks, advertising posters, etc. and its arrangement in response to human activities and needs. Recommendations to analyze human behaviour (movement of pedestrians, the overall atmosphere of the centres where people meet and the place where most activity takes place) are mentioned also in the methodology for assessing public spaces discussed by Chapman and Larkham (1992).

\section{Observation of Public Spaces}

Gehl's methodology was first mentioned in his book: Life between Buildings. This was developed and applied to public spaces in London (2004) in order to improve the quality of public spaces and public life. This methodology was designed by Gehl architects. The purpose of the observations was to determine how and by whom these public spaces are used and what facilities are provided for its users. Observations of public spaces were carried out in selected public spaces for 15 minutes every hour between 10.00 and 22.00. Activities, gender and the age of people were recorded from one place. The survey locations were chosen to provide the best possible overview of pedestrian traffic and have been determined in the initial public space analysis. Positions were recorded on prepared maps. During the observation were recorded gender (male, female), age (age groups: 0 - 6, 7 - 14, 15 - 30, 31 - 64, 65 and over), and activities (not pre-defined).

The methodology of operational improvement of public spaces developed by Vladimíra Šilhánková et al. (2006) is based on the principles of direct observation. This comes from Gehl's (2000) methodology, although edited and adapted. It evaluates the character and functions of public spaces and was proved in the creation of public spaces in Hradec Králové (CZ). The first part of the methodology focuses on the assessment of the character and quality of public spaces. The second focuses on the behaviour mapping in public spaces. Observations of selected public spaces were carried out for 20 minutes every hour. Activities, gender and the age of people were recorded during the walk from one site of public space to another. Frequency between the observations during the day in one public area was, on average every hour and depended on its type and the frequency of use. Šilhánková et al. (2006) use 3 types of forms where are observations recorded and summed up. During the observation the following data were recorded: gender, age (age groups: 0 - 6, 7 - 18, 19 - 60, 61 and over), activities (predefined: sitting, standing, eating, talking, walking with dog, shopping, looking to the shop windows, and other activities).

\section{Material and Methods}

The research described here is part of the work undertaken for a $\mathrm{PhD}$ in Landscape architecture (Lipovská, 2011) which explored the observation methods and their usage in landscape planning praxis. In this qualitative study data was obtained through direct observation in Vel'ké Zálužie village in Slovakia, $11 \mathrm{kw}$ away from Nitra city - the 5th largest city in Slovakia. The village has population of 4052 inhabitants.

No specific methodologies assessing the use of rural public areas - public spaces in villages - have been found. Therefore methodologies that analyse the quality and usage of public spaces in cities developed by Gehl (2000) and Šilhánková et al. (2006) have been used to characterize gender, age and activity level of community in rural settlement (see Table 1) and their potential use for landscape planning praxis have been assessed. These methodologies have been selected because there is a step-by-step manual of the observation process for the public spaces of cities that have been studied. 
Table 1.

Comparison of the methodologies.

\begin{tabular}{|c|c|c|}
\hline $\begin{array}{l}\text { Methodology/ } \\
\text { Part of the } \\
\text { methodology }\end{array}$ & Jan Gehl (2004) & $\begin{array}{c}\text { Vladimíra Šilhánková } \\
\text { et al. (1996) }\end{array}$ \\
\hline \multicolumn{3}{|c|}{ Public life (Second part of the methodology) } \\
\hline $\begin{array}{l}\text { Observation } \\
\text { time }\end{array}$ & 15 minutes & 20 minutes \\
\hline $\begin{array}{l}\text { Observation } \\
\text { position }\end{array}$ & $\begin{array}{l}\text { Observation from } \\
\text { one position }\end{array}$ & $\begin{array}{l}\text { Observation by walking } \\
\text { from one site of the area } \\
\text { to another site. }\end{array}$ \\
\hline $\begin{array}{l}\text { Observation } \\
\text { forms }\end{array}$ & $\begin{array}{l}\text { Based on information } \\
\text { was developed simple } \\
\text { form to record notes } \\
\text { Forms include the } \\
\text { gender, age and } \\
\text { activities-people are } \\
\text { observed individually }\end{array}$ & $\begin{array}{l}\text { Existed forms- } \\
\text { different types } \\
\text { Forms includes number } \\
\text { of group, gender, age, } \\
\text { activities- people are } \\
\text { observed as a group }\end{array}$ \\
\hline Age groups & $\begin{array}{l}0-6,7-14,15-30 \\
31-64,65 \text { and more }\end{array}$ & $\begin{array}{c}0-6,7-18,19-60 \\
61 \text { and more }\end{array}$ \\
\hline Activities & No pre-defined & $\begin{array}{l}\text { Pre-defined (sitting, standing } \\
\text { in raw, eating, talking, } \\
\text { walking with dog, shopping, } \\
\text { looking to the shop windows, } \\
\text { and other activities) }\end{array}$ \\
\hline $\begin{array}{c}\text { Direction of } \\
\text { movement }\end{array}$ & Yes (to map) & Yes (to map) \\
\hline $\begin{array}{c}\text { Frequency of } \\
\text { observation }\end{array}$ & $\begin{array}{l}\text { - } \text { From } 10 \text { am to } \\
10 \text { pm-Every hour } \\
\text { Minimum } 2 \\
\text { observations-week day } \\
\text { and weekend } \\
\text { - } \quad \text { defined nice weather } \\
\text { - defined } 2 \text { seasons }\end{array}$ & $\begin{array}{l}\text { Time schedule not } \\
\text { defined-every hour } \\
\text { Minimum } 2 \\
\text { observations-week } \\
\text { day and weekend } \\
\text { - not defined the weather } \\
\text { - not defined seasons }\end{array}$ \\
\hline
\end{tabular}

\section{Case Study Village—Vel'ké Zálužie}

The tool is based on momentary time sampling to make systematic observations of target-areas. Target-areas are predetermined observation areas, used and visited by people. Three central public spaces were chosen to allow observation as many people as possible (see Figures 1 and 2) and were selected of different sizes and location. A typology of selected public spaces was characterized by Šilhánková et al. (2006) as square, street, vegetation area or other area (such as a parking lot).

Rínok Street (1) begins at a crossroad in the front of the entrance to the psychiatric hospital and ends on the main street crossroad. Based on the street profile, Rinok Street could be divided in two parts; from the clinic crossroad to the area in front of the church (1st part) and from the area in front of the church to main street crossroad (2nd part). The first part of the street is characterized by pavement on sides, wide front gardens and green areas between the pavements and the houses. Along the road is planted an alley of trees that ends at the area in front of the church. From there towards the main road (second part of the street) the street is without pavement, and front gardens are not so wide. At the end of this part, front gardens are used as parking spaces and houses are closer to the road.

The area of the Main Street (2) begins at the crossroad with Rínok Street (1) (opposite the post office) and ends behind the

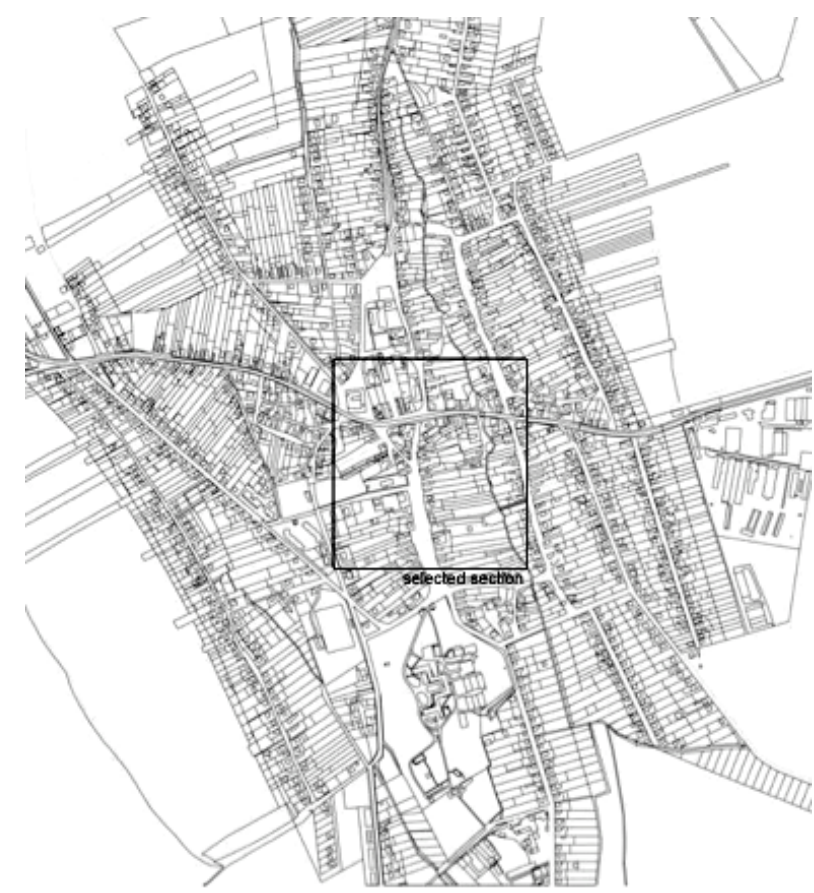

Figure 1.

Cadastral map of Vel'ké Zálužie village.

grocery shop (near the bus station). It is one of the principal and most frequented streets in the village. The main road cuts the street and whole village in half and it is a big barrier for pedestrian and cyclists. The observed area has pavement only on one side, where a new bus stop is located. The other side of the street has a bus stop with no pavement and no appropriate surface for pedestrians. Shops, municipality and all-important services are located along this street.

The area in front of the grocery shop (3) is located in the centre of the village, close to the main road, which surrounds it from the south. Near the main road is a green area with a grassed surface, planted mainly with coniferous trees. There is a pavement between the green area and the shop. The area serves as an unorganized parking area.

\section{Data Collection}

The approach was developed to collect data that would demonstrate how daily use of public open spaces related to design of such spaces and what activities are characteristic for them. The first phase involved initial site observation to assess the areas involved in observation and to analyse the quality of public space. Initial observation also collected information on the range of activities, to allow for preparation of detailed data collection.

The detailed data collection for each public space involved systematic observations for four days - 2 week days in May 2010, June 2010, and 2 weekend days in July 2010 and August 2010 for 15 minutes every hour between 8:00 to 20:00. These months were chosen as a time when the weather was warm and pleasant for outdoor activities. The timings of observation were chosen to capture different patterns of use at different times of day and on different times of week. Data were recorded into prepared forms (see Table 2).

The direct observation involved a systematic walking at the 
Table 2.

Public life observation form.

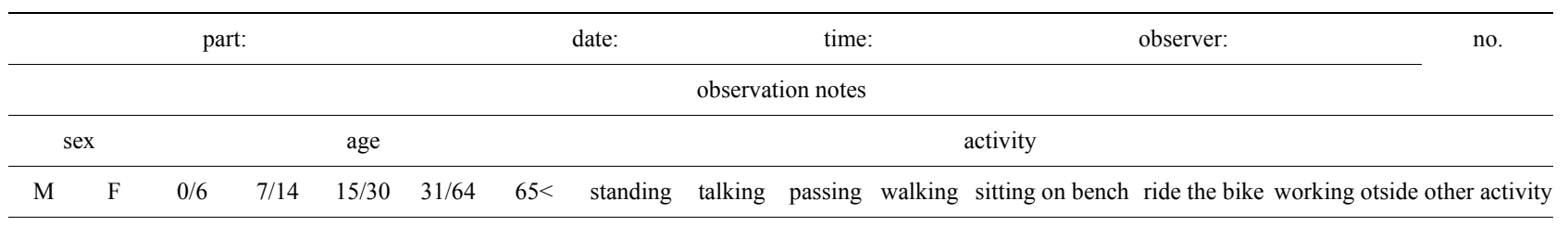
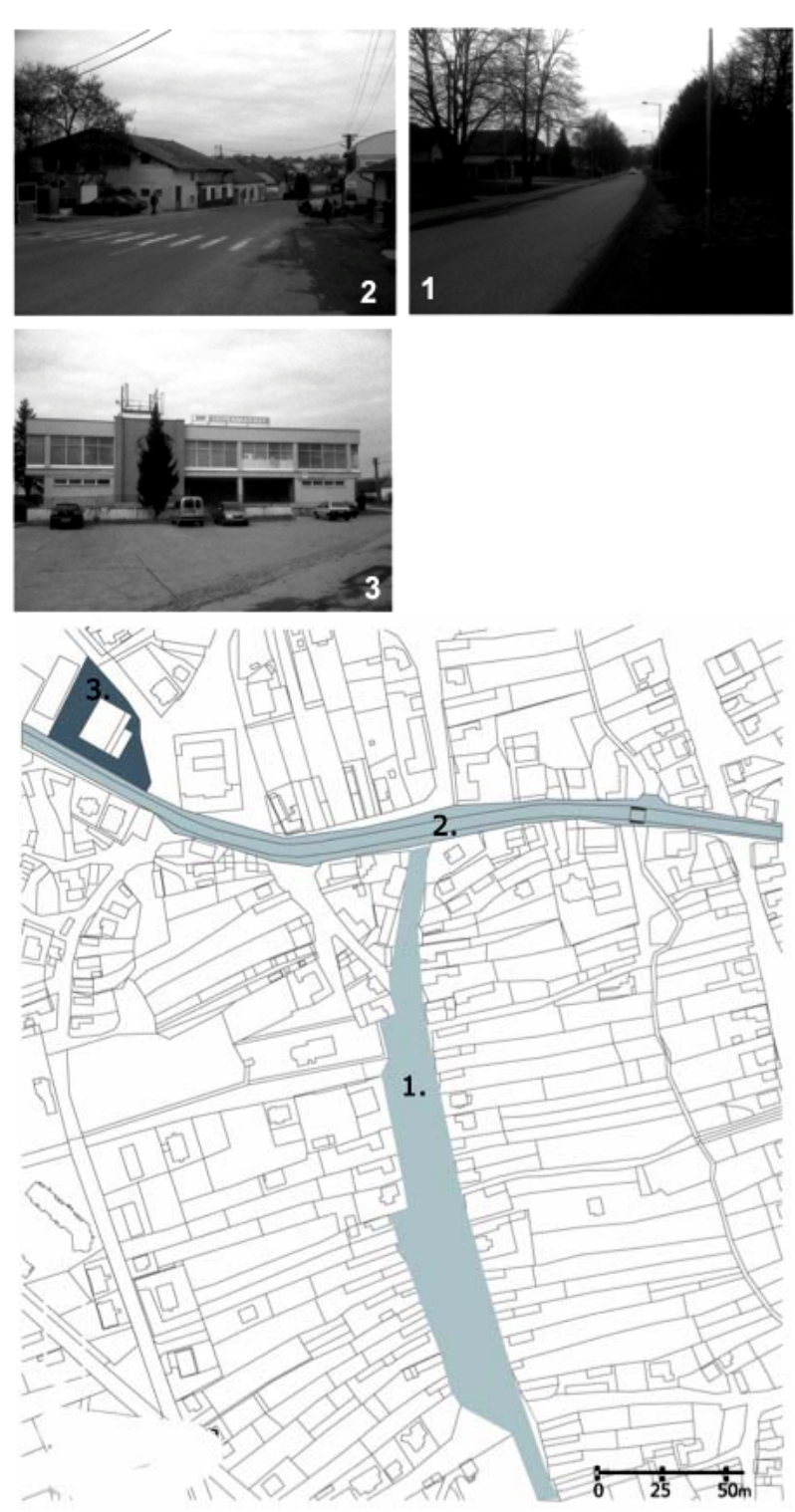

Figure 2.

Selected public spaces in Vel'ké Zálužie.

site. The observation form (see Table 2) records peoples' activities, gender and estimated age group. Age groups were divided into four groups $(0-6,7-14,15-30,31-64,65$ and more). One person could be recorded with more than one activ- ity. Activities were divided in three groups after observation identified their character. They were characterized using the activity description listed by Gehl and Gemzoe (1996) as necessary activities, optional activities and social activities. Necessary activities occur regardless of the quality of the physical environment because people are compelled to carry them out (such as going to school, waiting for the bus, shopping and going to work). The Optional activities are those which people are tempted to do when climatic conditions, surroundings and the place are generally inviting and attractive. Social activities occur whenever people move about in the same spaces. These may include watching, listening, and interacting with other people, passive and active participation.

Observation notes were included in the observation form. They were done immediately after the observation and comprised description of setting, people, behaviour, public space, everything that happened, the place where most social activities happened, and the observer's reflective comments on observation. The weather condition-temperature, wind, dryness and sunshine-for each observation period was also recorded.

As an observer is important to keep in mind that the most important behavioural principle during the observation is to be discreet. Try not to stand out or to affect the natural flow of activity (Jorgensen, 1989). One way to do this is to behave in a way similar to the people around you. Therefore, I recommend mask the observation forms (with the newspapers for example) or watch the activities from car or from restaurant (pub) terrace or coffee shop. According to Spradley (1980) when we observe people on public spaces the obtrusiveness is limited and the observed visibility is reduced. Observation may be done individually, in pairs, and in teams - whichever arrangement is most appropriate for covering the locations and topics at issue.

\section{Results}

On the basis of direct observation we obtained data assessing the quality of selected public spaces and their usage. All three selected public spaces are within walking distance $400 \mathrm{~m}$ and in terms of their importance for the people, all public spaces are significant for whole village and are used by people everyday.

\section{Quality of Public Space}

Vegetation in the village is presented in the form of private, semi-public and public green spaces that represented at least and with mainly aesthetic nature. The green areas include mainly evergreen coniferous trees that were planted in the $50 \mathrm{~s}$ and 60 s years, which despite of good maintenance have static and anaesthetic look. Public greenery in the village is presented 
in form of green areas, especially around the monuments and the memorials or as grass strips with planting along the road and in front of houses. Strips of grass are usually interrupted in front of the each house by concrete to provide an access for cars.

Direct observation of the quality of public space confirmed that the village has two types of seating possibilities: secondary seating and private seating. Both of them are located on the Main Street (2), where was observed that people use the con crete planters and low concrete fences as places to sit. On the main street were also observed the private benches of local ice cream shop. On the Rínok Street (1) or on the Area in front of the shop (3) people also use the low concrete fences as a secondary seating possibility.

Local people drive cars to groceries, shops, restaurants or to church. The car phenomenon is multiplied by oversized main road in the village. Asphalt and open public spaces in the earlier morning and evening hours serve as unorganized parking places Observation proved, that cars clash with pedestrians mainly on Main Street (3) where shops are located on both side with narrow pathways. In a village is also evident the cyclist transportation according to observations.

No parking areas along the street and any permission to stop the car allow the stakeholders to stop the car directly in front of the shop or kiosk entrance (Figure 3). Figure 4 shows a group of teenagers gathering on the Main Street (2) near the bus station that serves also as the public bench and provide the protection against the rain or sun. Observation has proven that this place is chosen quite often for talking or sitting and observing the other people. Although the quality of public space is because of the missing benches and narrow pathways not good, people use this place and many social activities occur here.

\section{Public Life}

The empirical evidence about usage and spatial relationships in the chosen public spaces is discussed on the basis of patterns observed on a particular day or on the basis of notes that were taken during the observation. Chart 1 shows the patterns of public space use during the week and weekend days.

A total of 3450 individuals were observed in selected streets and squares during four days and 4508 activities were recorded. Main Street (2) was the most common area found (40\%), followed by Rínok Street (1) (35\%). A total of 1420 inhabitants were observed on public spaces during the weekday $(65 \%$ women) and 2030 on weekends ( $60 \%$ women). Individuals in Main Street (2) were more sedentary and acting more social than in Rínok Street (1) or in the area in front of the grocery shop (3). Men and women use public spaces in a balanced way and the total number of activities is divided between men and women equally. More women (46\%) were observed talking and standing on the Main Street (2) than in Rínok Street (1) (34\%). Women use public spaces more often during the weekends and the analysis of the activities for each gender shows that women tend to more perform the optional activities. Men, on the basis of observations perform more necessary activities than women. Social activities were observed without significant differences.

Village people use the central public spaces daily. People pass them on their way to home from work, to a restaurant or pub, shops, etc. This is confirmed by the results of the observation, when there was an increased concentration of citizens' in the afternoon (after 14.00). Daily records of observed people

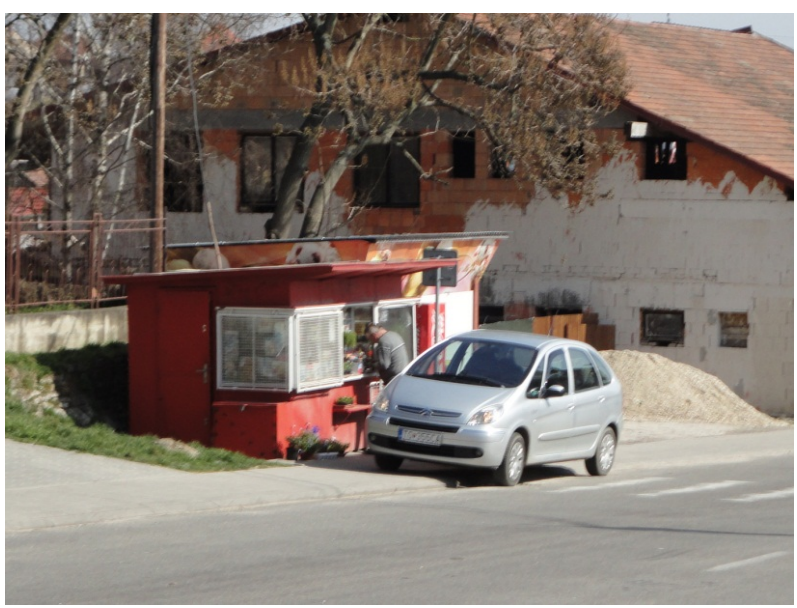

Figure 3.

The car is King. To buy cigarettes a man parked his car in front of the kiosk.

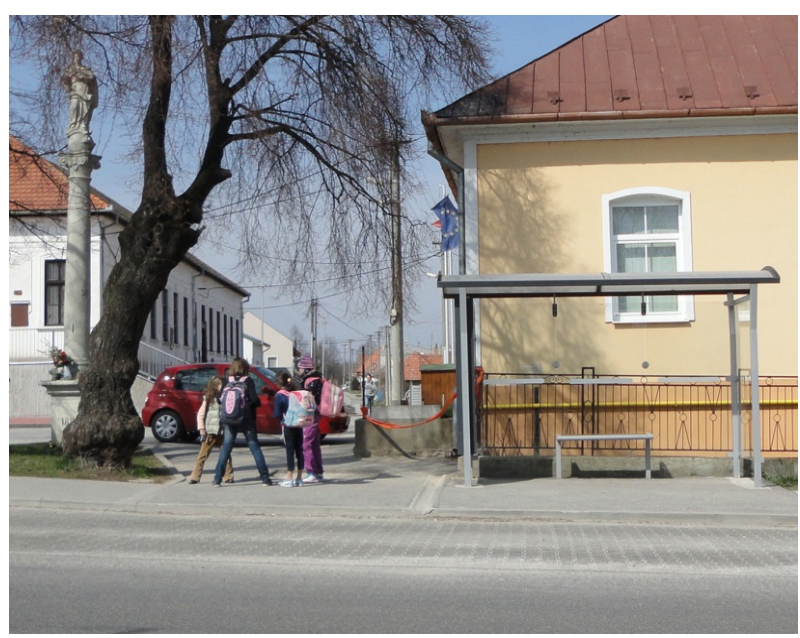

Figure 4.

Meeting point for school girls close to bus station on main street.

shows that most observed activities were necessary activities, with the largest representation of the passing area activity. Optional activities were recorded mostly on the Main Street (2). This fact confirms that the main streets are still seen as the main vein of the village. Although the observed Main Street (2) serves mainly to passing cars, activities such as cycling or roller-skating were observed. This could be explained that in peoples' mind the village streets are still seen as safe places for children. Although on the street are any public seating opportunities, people use this place for social activities such as talking.

The examination of all three observed places reveals that talking was the only social activity, which was recorded very often (on at least $70 \%$ of observed social activities). Different groups in terms of size, age and gender mix were recorded but the size of the talking groups was no more than 4 people. Big groups were typical for age groups 8 - 15 (Figure 5). Women were more talkative than men and usually formed the group of three persons. Pedestrians' meeting and talking points are located off the sidewalks, but on the paths of movement of pedestrians. This meeting places could be characterized as a spontaneous meeting place, which, even though unorganized 

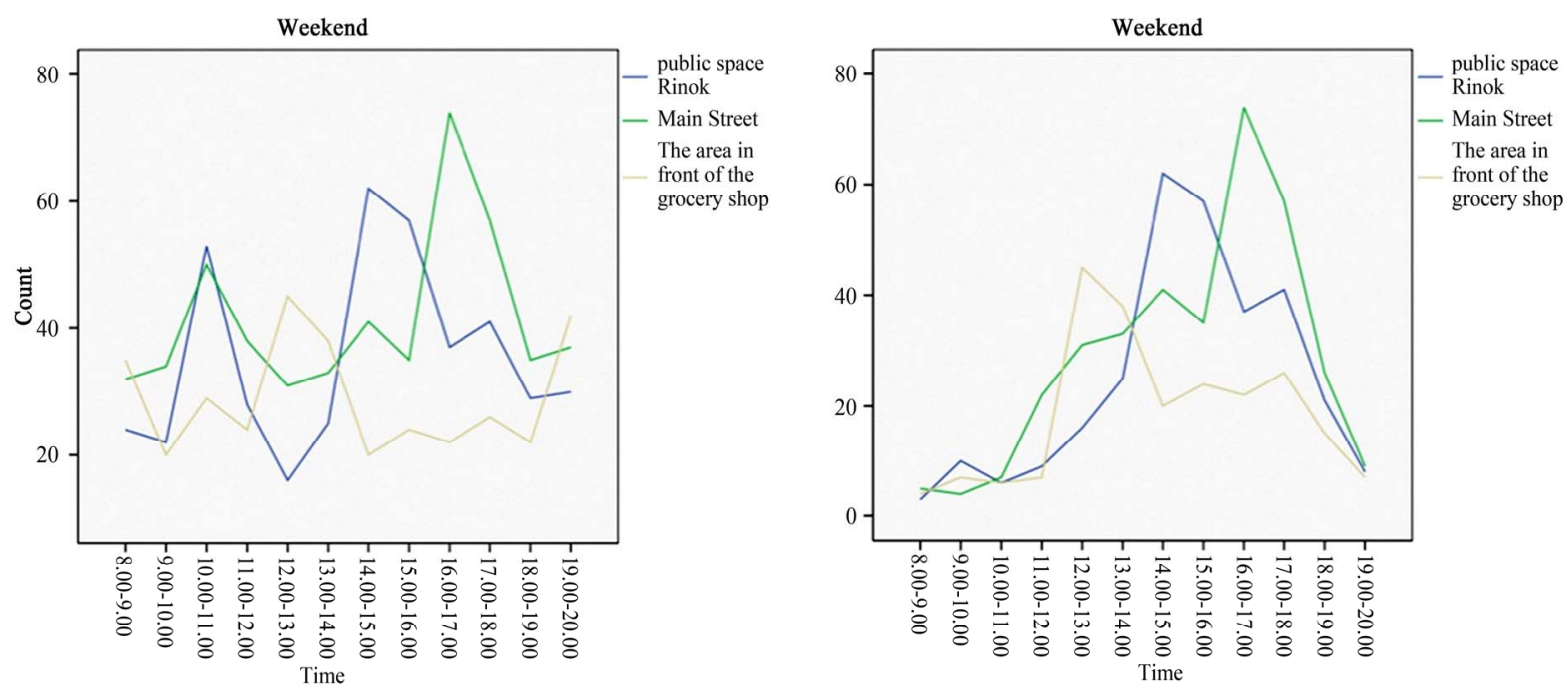

Chart 1.

Numbers and times of week and weekend observed people in selected public spaces (SPSS program).

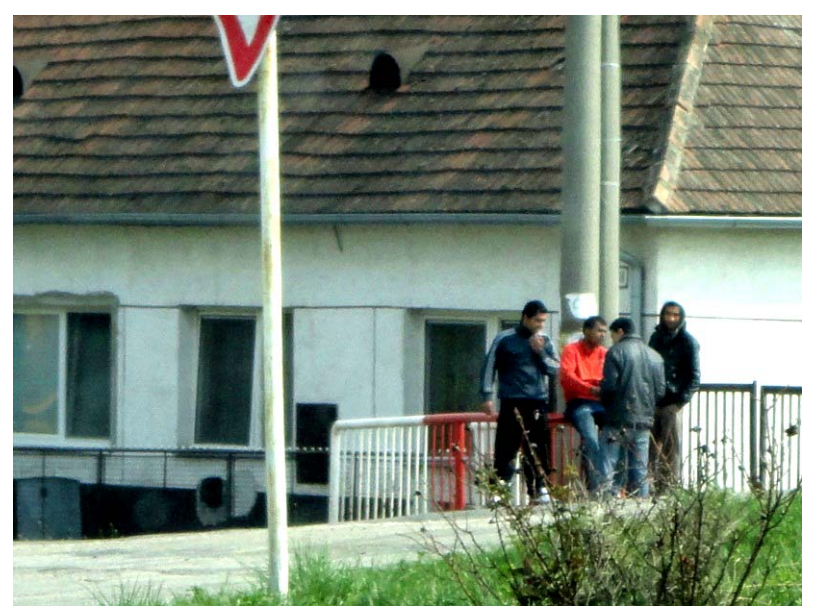

Figure 5.

Chatting point close to the area in front of the grocery shop he car is King. To buy cigarettes a man parked his car in front of the kiosk.

place there is always meeting place in a certain place in a public place.

\section{Discussion}

On the method of direct observation and comparison of results from studies that have been made in the urban environment, we can conclude that people in rural areas use public spaces, like in cities. Children under 6 years use public spaces usually accompanied by an adult, because the ability of independent movement is limited. Children in the age group of 7 14 years are able to move in the village without any support. In addition to the bus they haven't any another choice to independent movement outside the village. This age group is fully dependent on public life at local public places. Observation shows that these children prefer isolated public spaces that are protected from direct view of other people. Observation confirmed the theory that boys in this age use public space differently than girls. While boys prefer collective and sports games, girls use public spaces rather for sitting and talking activities.
Adolescents aged 15 - 30 years using the public spaces, like other older age groups. This age group is not completely reliant on public spaces in rural settlements. Their movement radius is larger. People in this age attend high school or university outside the village and from 18 tich years, thanks to the driving license and the car can move around freely. Age group $31-64$ encompasses a number of social statuses, from single men and women, married women and married men, unmarried and divorced mothers, working men and women and mothers on maternity leave. It includes the unemployed, people who spend all day in the villages well. Everyone is included in several statuses, which also affects the use of public space. In these cases is preferred universal design, which should be aimed to women and their needs. Women in this age prefer social and optional activities on public spaces more than men, who prefer necessary activities. People in the age group 65 and over are quite in the same situation as the group $7-14$. The possibility to travel freely outside of the village is limited and people are dependent on public life in the village. They prefer public places where there are other people in order to contact them or observed them. This fact is confirmed by the observation when this age group performed social activities such as talking and observing the surroundings. Social activities in the areas of squares and streets are common as well as in rural areas. This finding demonstrates that rural public spaces are becoming more social and intimate, as a city and people have to come closer. This fact should also be used in planning public spaces, which can be more personal in the countryside than in town.

\section{Conclusion}

In recent years, people's behaviour has become attractive not only for psychologists and sociologists but also for urban planners, architects, landscape architects and all those involved in designing people's environment. Community has its own interest in the site that we should consider. This paper identifies people-space relations and reflects on the implications from theory and practice in landscape architecture, in relation to the use and potentially physical change to public open space in rural settlements. It aims to show that people should matter first 
when making good outdoor public places. In designing public spaces in people-friendly ways we design in a philosophy of sustainable development, because people do not have to move to bigger cities for public interaction and engagement. By using the observation methodology we can obtain information about the users of public spaces (age and gender) and how public spaces are used (activities).

Not many villages have statistics on users of public spaces and the existence of a document that analyses the community from this perspective could be helpful in planning process. Based on the results of direct observation there is no difference in using public spaces for men and women and the level of social life in the Vel'ké Zálužie village is good and public spaces have the potential to be used and visited by people for purpose of social activities. Thanks to high traffic and location, the central public spaces have the greater potential and opportunity to attract more people. Seats are important elements in public places and their lack in the public space could change the place into transition zone with only a few spots where people stop and talk. Well-designed and located seats create resting places, people stay longer in public place and quality of public life is rising. Exterior seats have also economic benefits for surrounding buildings. Sitting on the cafes' or restaurants' terraces, have the same effect for improving the quality of public life as the public seating. While people are sitting in private places, their activities extend to public places. From this perspective, the physical condition of selected public spaces (target-areas) was evaluated as sufficient.

As landscape architects we design public spaces not just with vegetation but with the features of small architecture (such as outdoor furniture, paths, and playgrounds) as well. We affect not just an aesthetic and ecologic situation but also the social quality of public space. We enter into the public lives of the inhabitant and the information obtained from direct observation method is useful as a dialogue between community and designer. Their possible use for landscape architects could be in:

- The use of public spaces (How is public space used and by whom?) - is known the number of people, their age, their activities).

- For location of roads and paved areas and character of their surface (Are the paths and routes suitable for everybody? Do we have enough pavements?) - was observed how and where people move, the age of the people using the public space, disabled people.

- The number, shape and location of rest areas and their equipment (Are there enough resting seating and observing opportunities? Is there shelter to protect from sunlight?) - is known what kind of activities taking place on public space and if they need special equipment or places, is known who visits the public space.

The shelters, benches and rest areas are important for the quality of public life.

- Location of green areas and playgrounds - is known where people move and what places are most visited. This information is helpful for design of green areas that should be visited by local people.

- In the design of active sites and their target groups such as children's playgrounds, playgrounds for teenagers, or sport areas for seniors (Are there enough opportunities for creative and exploratory activities?)

- Selection and location of plants and the overall visual modification site of public space (Is there shade to protect people from bright sunlight?) - distribution of plants and vegetation could help to develop some activities and resting areas, especially those with natural character. Under the shade of the trees you can find a place for some activities, especially in hot summer days.

- Monitoring quality of public space - based on activities and the number of people who visit the public space we can evaluate the public space as having higher or lesser importance for inhabitants. Most important public spaces, that create a place for social and optional activities, will be assessed as public spaces with social importance and their future renovation will have to take account of the current activities.

- We can create an activity map: Showing where people do things, which places they visit. This is useful for planning future facilities.

- To indicate the principles of future improvement - it can assist in the clearer definition of the design brief and point the way to design solutions.

\section{Acknowledgements}

The paper was created with the support of the Scientific Grant Agency VEGA under the project VEGA 1/0769/12 Creation of sustainable public spaces of rural settlements by using modern methods.

\section{REFERENCES}

Bechtel, R. B., et al. (1987). Methods in environmental and behavioural research. New York: Van Nostrand Reinhold.

Carmona, M., et al. (2003). Public places, urban spaces. Oxford: Architectural Press.

Carr, S. (1992). Public space. Cambridge: Cambrige University Press

Chapman, D., \& Larkham, P. J. (1992) Discovering the art of relationship: Urban design. Birmingham: University of Central England.

Damyanovic, D., \& Reinwald, F. (2008). Leitlinie der Gemeinde Lengau für eine flächen und kostensparende Bauland und Siedlungsentwicklung unter Beachtung von geschlechts, alters und gruppenspezifischen Anforderungen mit dem Ziel der Chancengleichheit für Frauen und Männer, Jung und Alt. Self-publication Guideline of the community Lengau for an area-and cost-saving land and settlement development, Having regard to sex, age and group-specific needs with the goal of equal opportunities for women and men, young and old. Self publication, BOKU, Germany.

Forsyth, A. (2007). Innovation in urban design: does research help? Journal of Urban Design, 12, 461-473. http://dx.doi.org/10.1080/13574800701602569

Francis, M. (1984). Mapping downtown activity. Journal of Architecture and Planning Research, 1, 21-35.

Frick, D. (2007). Spatial synergy and supportiveness of public space. Journal of Urban Design, 12, 261-274. http://dx.doi.org/10.1080/13574800701306369

Gehl, J. \& GehlArchitects (2000). Public Space, Public Life Survey. http://www.gehlarchitects.dk/

Gehl, J. \& GehlArchitects (2000). Towards a Fine City for People. http://www.gehlarchitects.dk/

Gehl, J. \& Gemzoe, L. (1996). Public Spaces. Public Life. Copenhagen, Denmark: The Danish Architectural Press and Royal Danish Academy of Fine Arts, School of Architectural Publishers.

Gehl, J. (2000). Život mezi budovami-Life between buildings. Brno, CZ: Nadace Partnerství.

Hough, M. (1990). Out of Place: Restoring Identity to the Regional Landscape. New Haven: Yale University Press.

Ittelson, W. H., et al. (1970). The use of behavioural maps in environmental psychology. In H. M. Prohansky, W. H. Ittelson, L. G. Rivlin (Eds.), Environmental Psychology: Man and his Physical Setting, 


\section{B. LIPOVSKÁ, R. ŠTĚPÁNKOVÁ}

Holt (pp. 658-668). New York: Rinehart \& Winston.

Jacobs, J. (1962). The death and life of great American cities. London: Cape.

Koll, A. (2009). Der Laubeplatz in Wien Favoriten. Ph.D. Thesis, Wien: BOKU.

Lipovská, B. (2011). Dotvorenie verejných priestorov vidieckych sídiel uplatnením priamopozorovacích metód (Design of rural public spaces by a participant observation approach). Dissertation Thesis, Nitra: Slovak Agricultural University.

Lynch, K. (1960). Site planning. Cambrige: MIT Press.

Lynch, K. (1984). Site Planning. Revised Edition, Cambrige: MIT Press.

Madanipour, A. (1996). Design of urban space. Chichester, UK.

Marcus, C. C., \& Francis, C. (1998). People place. Design guidelines for urban open space (2nd ed.). New York: John Wiley and Sons.

Marcus, C. C. (1998). People places. New York: John Wiley.

Muchow, M. (1966). Der Lebensraum des Grosstandkindes: The Living space of the big city child. Buchverlag: Pad.-extra.

Porta, S., Crucciti, P., \& Latora, V. (2008). Multiple centrality assessment in Parma: A network analysis of paths and open spaces. Urban Design International, 13, 41-51. http://dx.doi.org/10.1057/udi.2008.1

Porta, S., et al. (2009). Street centrality and densities of retails and services in Bologna, Italy. Environment and Planning B: Planning \& Design, 36, 450-465. http://dx.doi.org/10.1068/b34098
Project for Public Spaces (PPS) (2001). How to turn a place around: A handbook for creating successful public spaces. New York: Project for Public Spaces.

Spradley, J. (1980). Participant observation. Fort Worth. London: Harcourt Brace.

Jovanovich (1980). $195 \mathrm{~s}$.

Šilhánková, V., et al. (2006). Veřejné prostory jako prostředek pro podporu místního cestovního ruchu-Public spaces as a means to promote local tourism. Hradec Králové: Civitas per populi.

Štepánková, et al. (2012). Design Principles of public and recreational areas in the urban environment. Nitra, Slovakia: Slovak University od Agriculture.

Thwaites, K., et al. (2005). Restorative urban open space: Exploring the spatial configuration of human emotional fulfilment in urban open space. Landscape Research, 30, 525-547. http://dx.doi.org/10.1080/01426390500273346

Tilley, J., et al. (1996). Metodika operativního zlepšení veřejného prostoru-Methodology operational improvement of public space. Magistrát města Brna, CZ: US Peace Corps.

Wheeler, S. (2004). The sustainable urban development reader. London: Routledge.

Whyte, W. H. (1980). The social life of small urban spaces. Washington DC: The Conservation Foundation. 